\title{
Investigating and Comparing Primary, Secondary, and High School Principals' and Teachers' Attitudes in the City of Isfahan towards In-Service Training Courses
}

\author{
Masoud Foroutan (Corresponding Author) \\ PhD Student of Educational Administration, Department of Educational Sciences \\ Faculty of Educational Sciences and Psychology, University of Isfahan
}

Saeed Rajaeepour

Associate Professor, Department of Educational Sciences

Faculty of Educational Sciences and Psychology, University of Isfahan

Seyed Ali Siadat

Professor, Department of Educational Sciences

Faculty of Educational Sciences and Psychology, University of Isfahan

Received: January 12, 2016 Accepted: February 02, 2016 Published: February 28, 2016

doi:10.5296/ijhrs.v6i1.9058 URL: http://dx.doi.org/10.5296/ijhrs.v6i1.9058

\begin{abstract}
One of the factors of improving teaching and learning as well as realization of aims of educational institutes depends on improving the quality of teachers' and principals' in-service educational courses. The present study aims at investigating principals' and teachers' attitudes towards in-service course in Isfahan City. The research method employed in the study was descriptive and the data collection method was the survey research. The population includes all teachers and principals in the City of Isfahan. Participants were selected using proportionate stratified random sampling method. The sample size included 284 participants. The data collection instrument was a researcher-made questionnaire including 46 close-end questions designed based on the five-point Likert scale. Its reliability was obtained as $95 \%$ based on Cronbach's alpha coefficient in the pilot study. Comparing male and female participants' attitudes regarding professors and lecturers of in-service educational courses indicated significant differences. In other words, female participants evaluated the degree of
\end{abstract}


lecturers' skills as higher than male ones did. But, no significant difference was observed regarding educational needs, textbook contents, assessment methods, environment and equipment, time of holding courses, and the increase in capabilities between male and female participants. No significant difference can be indicated the comparison of participants' attitudes regarding their educational sections (primary, secondary, and high schools) in relation with educational environment and equipment as well as the time of holding courses, but the attitudes of the same participants regarding educational needs, textbook content, assessment methods of professors and lecturers, the increase in their professional and scientific capabilities indicate no significant difference. In addition, participants' attitudes regarding educational sections and in terms of the increase in professors and lecturers' scientific and professional capabilities indicate a significant differences. In other words, primary school participants considered the increase in their own scientific and professional capabilities higher than those of high school participants.

Keywords: Attitudes, Principals, Teachers, In-service training

\section{Introduction}

Different organizations and institutions in a society are constructed based on specific objectives and based on these objectives, they do certain tasks and performances in the society and realize multiple needs. In other words, the raison d'être of each organization is providing different services for the society in line with objectives considered for that organization. In the past, due to the lack of complicatedness in the society and limitations in needs and innovations, organizations' functions were usually simple and everyone could prepared himself for doing that job in a short period of time.

In the contemporary world, due to the expansion of sciences and technologies as well as the diversification of scientific fields of study in different social, economic, cultural, and political dimensions, confirming preparedness for getting a job as easily as possible. In addition, even if a person has preparedness for getting a job, increasing advancement of sciences and technologies makes his knowledge and skills old and out of date. Therefore, the survival of individuals and organizations depends on the issue that information and skills are continuously updated and this important issue cannot be possible unless with continuous training.

Undoubtedly, training has a particular importance in humans' lives because training results in construction, improvement, and transcendence of human beings. The high status of human beings has been represented under the light of proper training and in fighting against calamities such as poverty, ignorance, illiteracy, superstitions, and different cultural, political, and economic biases makes human beings secure and capacities are realized accordingly. Training is one of the most complicated tasks in managing affairs in each organization, training causes the depth of visions and higher knowledge as well as more skills for individuals working in organizations for doing their own tasks and results in attaining organizational objectives with higher efficiency and effectiveness. 


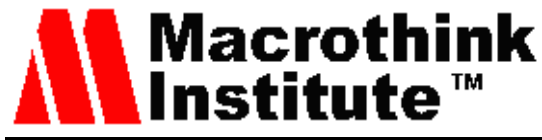

International Journal of Human Resource Studies

ISSN 2162-3058

Training has been always a safe instrument for improving quality of performances and solving problems of an organization and its absence is one of the most basic issues in each organization. The educational systems of an organization should be in such a way that appropriate with the rapid movement of new and required sciences and technologies, it can provides knowledge, and information for personnel in the organization to be prepared for doing their own tasks. Training is a set of human tasks in organizations and a continuous process not a transient one. In fact, training has always been an unending source of grace and light for the illumination of human souls as well as for reconstruction and purification of human beings in line with attaining higher virtues and attaining skills in the human paths.

"Specific trainings which has filled gaps of staff's job information and are related and compatible with needs for attaining objectives required by organizations. They are provided for increasing skills and efficiencies of staff in jobs required by organizations during doing services" (Kazemi, 1991, p. 198).

Before explaining the concept of in-service training and definitions related to its, it is worthy to speak of training itself. According to Mirkamali (1998) "training is the experience of learning which creates relatively permanent changes in invidiously and reforms their capabilities for doing some tasks. In other words, training gradually complements changes in skill, knowledge, attitudes or social behaviors" (p. 7).

The main objective of training is enhancing knowledge, information, and skills in individuals. Accordingly, training is a continuous process whose final aim is to enhance capabilities, proficiencies, and knowledge of individuals for doing tasks and personal development (Fathi and Ejargah, 2007, p. 9).

Since the nature of in-service trainings may be different from one organization to another, providing a comprehensive definition covering all these training s. according to Mirkamali (1998) "in-service trainings refer to those trainings provided for increasing efficiencies and proficiencies of individuals to formal staff and those under employment of an organization. In fact, in-service training starts when a person passes the stages of his employment in institutions" (p. 7).

John.F.M. (1978) defines in service training as "the systematic and consistent improvement of staff in terms of knowledge, skills, and behaviors which contribute to their welfare and organizations. Therefore, the main objective in-service training is to create more abilities in terms of production and increase efficiency in current jobs and attain better condition for qualification of higher statuses" (as cited in Fathi and Ejargah, 1994, p. 34).

May (1978) believes that in-service training refer to "systematic and consistent improvement of employees in terms of knowledge, skills, and behaviors helping them and their organizations. Therefore, it is imagined that the aim of in-service training is the creation of more products and the increase in efficiency in current jobs and attaining better conditions for achieving higher statuses (Fathi and Ejargah, 2007, p. 34). 


\section{Research questions}

1. To what extent is the need assessment of principals' and teachers' in-service training compatible with scientific methods of need assessment?

2. To what extent are course contents of in-service training compatible with principals' and teaches' educational needs?

3. To what extent are the assessment methods of principals' and teachers learning of in-service training compatible with scientific methods of assessment?

4. To what extent do lecturers of in-service training courses enjoy required professional skills?

5. To what extent do principals and teachers consider educational environments and equipment available in in-service training courses as appropriate?

6. To what extent do principals and teachers consider the time of holding in-service training courses as appropriate?

7. To what extent do principals and teachers consider in-service training courses as effective on increasing their own professional capabilities?

8. Is there any difference in principals' and teachers' attitudes towards in-service training courses based on demographic characteristics (gender, educational sections, years of services, status)?

\section{Research method}

The research method in the present study is a descriptive one and data collection method is a survey study. The population of the present study includes all principals and teachers of schools in the City of Isfahan who worked formally employed in in the academic year 2010-2011. In five area of the City of Isfahan and Jay Area, totally 15258 principals and teachers (13968 teacher and 1290 principals) worked. From among the population of teachers, 9380 individuals are female and 4588 individuals are male. In addition, from among the population of principals, 648 individuals are female and 642 individuals are male. To analyze the research data, descriptive statistics such as frequency, percentage, mean scores, and standard deviation, and inferential statistics such as univaraite two-independent sample t-test, ANOVA, Tukey test, and Friedman test were used.

To select a sample from teachers and principals, stratified random sampling was used. Frist of all, from among the five areas, three ones (areas 2, 4, and Jay Area) were randomly selected, and then a list of girl and boy schools in each area was received from the related offices and then, in each school, a number of principals and teachers were randomly selected.

The population of the study includes all principals and teachers of the City of Isfahan among whom a number of 284 individuals were randomly selected as the sample size using the stratified random sampling proportionate to size. 


\section{Data collection instrument}

The present study uses a researcher-made questionnaire with 46 close-ended items based on five-point Likert scale. Firstly, in the questionnaire, information about gender, educational sections, years of service, and educational level and fields of study was presented. To measure the validity of the questionnaire, content validity was used. Accordingly, by referring to scientific texts and theories related to the subject and research questions, the questionnaire was developed and submitted to the supervisor and advisor of the research. Then, after doing amendments by the research, content and formal validities of the questionnaire were confirmed. To estimate the reliability of the present questionnaire, Cronbach's alpha coefficient was used. It was obtained as $95 \%$ in the pilot study. A number of 84 copies of the questionnaire were randomly distributed among principals and all of them except 4 copies were returned. A number of 200 copies of the questionnaire were randomly distributed among teachers, among which 19 copies were incomplete and excluded and 181 copies were statistically analyzed.

\section{Data analysis}

In this section, the results of the analysis of main research questions are discussed:

1. To what extent is the need assessment of principals' and teachers' in-service training compatible with scientific methods of need assessment?

Analyzing findings related to the first research question mentioned in table 1 indicates that t-observedat the significance level $\mathrm{P} \leq 0.05$ was not significant and the mean scores recognizing needs of training participants in in-service training courses was equal with 2.59 and SD was 0.894 . Therefore, according to respondents of the present study, the mean scores of recognizing educational needs of participants of in-service training courses is lower than the moderate level and is compatible with scientific methods. The results of analyzing this question are consistent with those of Azar (2005), Brimm (1984), Edelfelt (1984), and Bunker (1987).

Table 1: comparing mean scores of respondents regarding recognizing educational needs of participants of in-service training courses with criterion scores

\begin{tabular}{|c|c|c|}
\hline Univariate t-value & SD & $\begin{array}{l}\text { Mean scores } \\
\bar{X}\end{array}$ \\
\hline-7.39 & 0.894 & 2.59 \\
\hline
\end{tabular}

In the present study, comparing ideas of male and female respondents has been indicated in table 8. Accordingly, there is no significant difference between their ideas regarding recognizing educational needs in in-service training courses at the significant level $\mathrm{P} \leq 0.05$. 


\section{Macrothink}

International Journal of Human Resource Studies

ISSN 2162-3058

2016, Vol. 6, No. 1

Therefore, there is no difference between male and female respondents' ideas regarding recognizing educational needs $(\mathrm{P}=0.482, \mathrm{~F}=0.871)$.

According to the results of table 9, comparing mean scores of respondents in terms of educational sections and regarding educational needs of in-service training courses is significant at the levelP $\leq 0.05(\mathrm{p}=0.001, \mathrm{~F}=7.721)$.

According to the results of table 10, comparing mean scores of respondents in terms of years of service and regarding educational needs of in-service training courses is not significant at the level $\mathrm{P} \leq 0.05(\mathrm{p}=0.482, \mathrm{~F}=0.871)$.

2. To what extent are course contents of in-service training compatible with principals' and teaches' educational needs?

Analyzing findings related to the first research question mentioned in table 2 indicates that t-observed at the significance level $\mathrm{P} \leq 0.01$ was significant and the mean scores course contents in in-service training courses was equal with 3.21 and SD was 0.843 . Therefore, according to respondents of the present study, the mean scores of course contents of in-service training courses is higher than the moderate level and is compatible with educational needs of the participants in-service training courses. The results of analyzing this question are consistent with those of TighsazZadeh (2002), Ghoshouni (2005), and Flatter and Koopman (1986).

Table 2: comparing mean scores of respondents course contents of in-service training courses with criterion scores

\begin{tabular}{|c|c|c|}
\hline Univariate t-value & $\mathrm{SD}$ & $\begin{array}{l}\text { Mean scores } \\
\bar{X}\end{array}$ \\
\hline 4.02 & 0.843 & 3.21 \\
\hline
\end{tabular}

In the present study, comparing ideas of male and female respondents has been indicated in table 8. Accordingly, there is no significant difference between their ideas regarding course contents of in-service training courses at the significant level $\mathrm{P} \leq 0.05$. Therefore, there is no difference between male and female respondents' ideas regarding recognizing educational needs $(\mathrm{P}=0.14, \mathrm{t}=1.74)$.

According to the results of table 9, comparing mean scores of respondents in terms of educational sections and regarding course contents of in-service training courses is significant at the level $\mathrm{P} \leq 0.05(\mathrm{P}=0, \mathrm{~F}=8.58)$.

According to the results of table 10, comparing mean scores of respondents in terms of years of service and regarding course contents of in-service training courses is not significant at the level $\mathrm{P} \leq 0.05(\mathrm{P}=0.14, \mathrm{~F}=1.74)$. 
3. To what extent are the assessment methods of principals' and teachers learnings of in-service training compatible with scientific methods of assessment?

Analyzing findings related to the first research question mentioned in table 3 indicates that t-observed at the significance level $\mathrm{P} \leq 0.01$ was significant and the mean scores of the assessment method of participants' learnings in in-service training courses was equal with 3.16 and SD was 0.637. Therefore, according to respondents of the present study, the mean scores of assessment method of participants' learnings of in-service training courses is higher than the moderate level and is compatible with scientific methods of assessment. The results of analyzing this question are consistent with those of Ghoshouni (2005) and Alexander (1986).

Table 3: comparing mean scores of respondents regarding the assessment method of participants of in-service training courses with criterion scores

\begin{tabular}{|c|c|c|}
\hline Univariate t-value & SD & $\begin{array}{l}\text { Mean scores } \\
\bar{X}\end{array}$ \\
\hline 1.4 & 0.637 & 3.16 \\
\hline
\end{tabular}

In the present study, comparing ideas of male and female respondents has been indicated in table 8. Accordingly, there is no significant difference between their ideas regarding the assessment method of participants' learnings of in-service training courses at the significant level $\mathrm{P} \leq 0.05$. Therefore, there is no difference between male and female respondents' ideas regarding the assessment method of participants' learnings of in-service training courses $(\mathrm{P} \leq 0.829, \mathrm{t}=0.371)$.

According to the results of table 9, comparing mean scores of respondents in terms of educational sections and regarding the assessment method of participants' learnings of in-service training courses is significant at the level $\mathrm{P} \leq 0.05(\mathrm{P} \leq 0.00, \mathrm{~F}=10.17)$.

According to the results of table 10, comparing mean scores of respondents in terms of years of service and regarding the assessment method of participants' learnings of in-service training courses is not significant at the level $\mathrm{P} \leq 0.05(\mathrm{P}=0.829, \mathrm{~F}=0.371)$.

4. To what extent do lecturers of in-service training courses enjoy required professional skills?

Analyzing findings related to the first research question mentioned in table 4 indicates that t-observed at the significance level $\mathrm{P} \leq 0.01$ was significant and the mean scores of professional skills of lecturers of in-service training courses was equal with 3.59 and SD was 0.724. Therefore, according to respondents of the present study, the mean scores of professional skills of lecturers of in-service training courses is higher than the moderate level. 


\section{Macrothink}

International Journal of Human Resource Studies

ISSN 2162-3058 2016, Vol. 6, No. 1

The results of analyzing this question are consistent with those of Ghoshouni (2005) Akhalghifar (1983), and Mangere and Mg Williams.

Table 4: comparing mean scores of respondents regarding professional skills of lecturers of in-service training courses with criterion scores

\begin{tabular}{|c|c|c|}
\hline Univariate t-value & SD & $\begin{array}{l}\text { Mean scores } \\
\bar{X}\end{array}$ \\
\hline 13.23 & 0.724 & 3.59 \\
\hline
\end{tabular}

In the present study, comparing ideas of male and female respondents has been indicated in table 8. Accordingly, there is no significant difference between their ideas regarding professional skills of lecturers of in-service training courses at the significant level $\mathrm{P} \leq 0.05$. Therefore, there is no difference between male and female respondents' ideas regarding professional skills of lecturers of in-service training courses $(\mathrm{P}=0.32, \mathrm{t}=1.406)$.

According to the results of table 9, comparing mean scores of respondents in terms of educational sections and regarding professional skills of lecturers of in-service training courses is significant at the level $\mathrm{P} \leq 0.05(\mathrm{P}=0.12, \mathrm{~F}=4.49)$.

According to the results of table 10, comparing mean scores of respondents in terms of years of service and regarding professional skills of lecturers of in-service training courses is not significant at the level $\mathrm{P} \leq 0.05(\mathrm{P}=0.232, \mathrm{~F}=1.406)$.

5. To what extent do principals and teachers consider educational environments and equipment available in in-service training courses as appropriate?

Analyzing findings related to the first research question mentioned in table 5 indicates that t-observed at the significance level $\mathrm{P} \leq 0.05$ was not significant and the mean scores of the environment and equipment available in in-service training courses was equal with 2.80 and SD was 0.719. Therefore, according to respondents of the present study, the mean scores of the environment and equipment available in-service training courses is higher than the moderate level. The results of analyzing this question are consistent with those of Javadian (2005) Ghoshouni (1983), Edelfelt (1984).

Table 5: comparing mean scores of respondents regarding the environment and equipment available in in-service training courses with criterion scores

\begin{tabular}{|c|c|c|}
\hline Univariate t-value & SD & $\begin{array}{l}\text { Mean scores } \\
\bar{X}\end{array}$ \\
\hline-4.47 & 0.719 & 2.80 \\
\hline
\end{tabular}


In the present study, comparing ideas of male and female respondents has been indicated in table 8. Accordingly, there is no significant difference between their ideas regarding the environment and equipment available in in-service training courses at the significant level $\mathrm{P} \leq 0.05$. Therefore, there is no difference between male and female respondents' ideas regarding the environment and equipment available in in-service training courses $(\mathrm{P}=0.881$, $\mathrm{t}=0.295)$.

According to the results of table 9, comparing mean scores of respondents in terms of educational sections and regarding the environment and equipment available in in-service training courses is not significant at the level $\mathrm{P} \leq 0.05(\mathrm{P}=0.708, \mathrm{~F}=0.3449)$.

According to the results of table 10, comparing mean scores of respondents in terms of years of service and regarding the environment and equipment available in in-service training courses is not significant at the level $\mathrm{P} \leq 0.05(\mathrm{P}=0.232, \mathrm{~F}=1.406)$.

6. To what extent do principals and teachers consider the time of holding in-service training courses as appropriate?

Analyzing findings related to the first research question mentioned in table 6 indicates that t-observed at the significance level $\mathrm{P} \leq 0.05$ was significant and the mean scores of the time of holding in-service training courses was equal with 3.14 and SD was 0.682. Therefore, according to respondents of the present study, the mean scores of the time of holding in-service training courses is higher than the moderate level and is consistent with appropriate time of holding these courses. The results of analyzing this question are consistent with those of Winterton(1987) and Batistoni (2001).

Table 6: comparing mean scores of respondents regarding the time of holding in-service training courses with criterion scores

\begin{tabular}{|c|c|c|}
\hline Univariate t-value & SD & $\begin{array}{l}\text { Mean scores } \\
\bar{X}\end{array}$ \\
\hline 3.44 & 0.682 & 3.14 \\
\hline
\end{tabular}

In the present study, comparing ideas of male and female respondents has been indicated in table 8. Accordingly, there is no significant difference between their ideas regarding the time of holding in-service training courses at the significant level $\mathrm{P} \leq 0.05$. Therefore, there is no difference between male and female respondents' ideas regarding the time of holding in-service training courses $(\mathrm{P}=0.597, \mathrm{t}=0.693)$.

According to the results of table 9, comparing mean scores of respondents in terms of educational sections and regarding the time of holding in-service training courses is not significant at the level $\mathrm{P} \leq 0.05(\mathrm{P}=0.745, \mathrm{~F}=0.29)$.

According to the results of table 10, comparing mean scores of respondents in terms of years 


\section{Ml Macrothink}

of service and regarding the time of holding in-service training courses is not significant at the level $\mathrm{P} \leq 0.05(\mathrm{P}=0.597, \mathrm{~F}=0.693)$.

7. To what extent do principals and teachers consider in-service training courses as effective on increasing their own professional capabilities?

Analyzing findings related to the first research question mentioned in table 7 indicates that t-observed at the significance level $\mathrm{P} \leq 0.01$ was significant and the mean scores of the increase in scientific and professional capabilities of participants of training courses was equal with 3.32 and SD was 0.762 . Therefore, according to respondents of the present study, the mean scores of the increase in scientific and professional capabilities of participants of in-service training courses is higher than the moderate level. The results of analyzing this question are consistent with those of ZarrinGohar (1987) Izadi (2002), Brimm (1984), Sakokok (1986), and Mangere and Mg Williams (1986).

Table 7: comparing mean scores of respondents regarding the increase in scientific and professional capabilities of participants of in-service training courses with criterion scores

\begin{tabular}{|c|c|c|}
\hline Univariate t-value & SD & $\begin{array}{l}\text { Mean scores } \\
\bar{X}\end{array}$ \\
\hline 6.78 & 0.726 & 3.32 \\
\hline
\end{tabular}

In the present study, comparing ideas of male and female respondents has been indicated in table 8. Accordingly, there is no significant difference between their ideas regarding the increase in scientific and professional capabilities of participants of in-service training courses at the significant level $\mathrm{P} \leq 0.05$. In other words, there is no difference between male and female respondents' ideas regarding the increase in scientific and professional capabilities of participants of in-service training courses $(\mathrm{P}=0.006, \mathrm{t}=3.712)$.

According to the results of table 9, comparing mean scores of respondents in terms of educational sections and regarding the increase in scientific and professional capabilities of participants of in-service training courses is not significant at the level $\mathrm{P} \leq 0.05(\mathrm{P}=0.012$, $\mathrm{F}=4.47)$.

According to the results of table 10, comparing mean scores of respondents in terms of years of service and regarding the increase in scientific and professional capabilities of participants of in-service training courses is significant at the level $\mathrm{P} \leq 0.01$. 


\section{Macrothink}

International Journal of Human Resource Studies

ISSN 2162-3058

Table 8: comparing mean scores of male and female respondents regarding research variables

\begin{tabular}{|c|c|c|c|c|c|c|}
\hline \multirow[b]{2}{*}{ Main research questions } & \multicolumn{2}{|c|}{ Principals } & \multicolumn{2}{|c|}{ Teachers } & \multirow[b]{2}{*}{$\begin{array}{l}\text { Two } \\
\text { independent } \\
\text { group t-test }\end{array}$} & \multirow[b]{2}{*}{ p-value } \\
\hline & $\begin{array}{l}\text { Mean } \\
\text { scores } \\
\bar{X}\end{array}$ & SD & $\begin{array}{l}\text { Mean } \\
\text { scores } \\
\bar{x}\end{array}$ & SD & & \\
\hline $\begin{array}{l}\text { 1. Educational needs of in-service } \\
\text { training courses }\end{array}$ & 2.54 & 0.860 & 2.61 & 0.914 & 0.564 & 0.573 \\
\hline $\begin{array}{l}\text { 2. Course contents of in-service } \\
\text { training courses }\end{array}$ & 3.09 & 0.885 & 3.27 & 0.813 & 1.738 & 0.083 \\
\hline $\begin{array}{l}\text { 3. Assessment methods of } \\
\text { in-service training courses }\end{array}$ & 3.13 & 0.630 & 3.17 & 0.643 & 0.597 & 0.551 \\
\hline $\begin{array}{l}\text { 4. Teachers and principals of } \\
\text { in-service training courses }\end{array}$ & 3.45 & 0.727 & 3.67 & 0.712 & 2.367 & 0.019 \\
\hline $\begin{array}{l}\text { 5. Educational environments and } \\
\text { equipment of in-service training } \\
\text { courses }\end{array}$ & 2.80 & 0.702 & 2.97 & 0.731 & 0.054 & 0.957 \\
\hline $\begin{array}{l}\text { 6. Time of holding in-service } \\
\text { training courses }\end{array}$ & 3.16 & 0.630 & 3.13 & 0.711 & 0.258 & 0.797 \\
\hline $\begin{array}{l}\text { 7. Increase in scientific and } \\
\text { professional capabilities } \\
\text { inin-service training courses }\end{array}$ & 3.24 & 0.776 & 3.36 & 0.754 & 1.15 & 0.251 \\
\hline
\end{tabular}

According to the results of table 8, t-observed regarding lecturers was not significant at the level $\mathrm{P} \leq 0.05$; therefore, there is a significant difference between male and female respondents' ideas. In other words, female respondents have evaluated the degree of lecturers' skills as higher than male respondents have done. But t-observed regarding other factors at $\mathrm{P} \leq 0.05$ was not significant. 


\section{I Macrothink}

International Journal of Human Resource Studies

ISSN 2162-3058

Table 9: comparing mean scores of respondents' ideas in terms of educational sections regarding research variables in in-service training courses

\begin{tabular}{|c|c|c|c|c|c|c|c|c|}
\hline \multirow[t]{3}{*}{ Main research questions } & \multicolumn{2}{|c|}{$\begin{array}{l}\text { Primary } \\
\text { school }\end{array}$} & \multicolumn{2}{|c|}{$\begin{array}{l}\text { Secondary } \\
\text { school }\end{array}$} & \multicolumn{2}{|c|}{ High school } & \multirow{3}{*}{$\begin{array}{l}\text { ANO } \\
\text { VA } \\
\\
\text { F }\end{array}$} & \multirow{3}{*}{$\begin{array}{l}\text { Sig. } \\
\\
\text { P }\end{array}$} \\
\hline & $\begin{array}{l}\text { Mea } \\
\text { n } \\
\text { score } \\
\text { s }\end{array}$ & SD & $\begin{array}{l}\text { Mea } \\
\text { n } \\
\text { score } \\
\text { s }\end{array}$ & SD & $\begin{array}{l}\text { Mea } \\
\text { n } \\
\text { scor } \\
\text { es }\end{array}$ & SD & & \\
\hline & $\bar{x}$ & & $\bar{x}$ & & $\bar{x}$ & & & \\
\hline $\begin{array}{l}\text { 1. Educational needs of } \\
\text { in-service training } \\
\text { courses }\end{array}$ & 2.83 & 0.961 & 2.46 & 0.827 & 2.46 & 0.765 & 7.721 & 0.001 \\
\hline $\begin{array}{l}\text { 2. Course contents of } \\
\text { in-service training } \\
\text { courses }\end{array}$ & 3.42 & 0.755 & 3.18 & 0.855 & 2.91 & 0.868 & 8.58 & 0.000 \\
\hline $\begin{array}{l}\text { 3. Assessment methods } \\
\text { of in-service training } \\
\text { courses }\end{array}$ & 3.35 & 0.606 & 3.09 & 0.646 & 2.94 & 0.597 & 10.17 & 0.000 \\
\hline 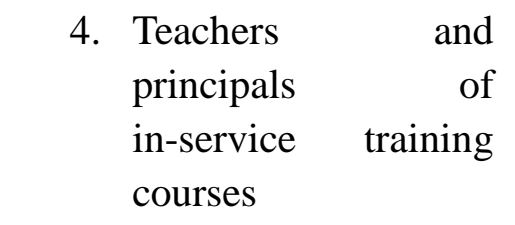 & 3.74 & 0.66 & 3.52 & 0.76 & 3.43 & 0.73 & 4.49 & 0.012 \\
\hline $\begin{array}{lr}\text { 5. } & \text { Educational } \\
\text { environments and } \\
\text { equipment r of } \\
\text { in-service } \\
\text { courses }\end{array}$ & 2.76 & 0.72 & 2.81 & 0.72 & 2.84 & 0.70 & 0.34 & 0.708 \\
\hline $\begin{array}{l}\text { 6. Time of holding } \\
\text { in-service } \\
\text { courses }\end{array}$ & 3.12 & 0.73 & 3.12 & 0.69 & 3.19 & 0.59 & 0.29 & 0.745 \\
\hline $\begin{array}{l}\text { 7. Increase in scientific } \\
\text { and professional } \\
\text { capabilities }\end{array}$ & 3.48 & 0.69 & 3.24 & 0.76 & 3.16 & 0.81 & 4.47 & 0.012 \\
\hline
\end{tabular}


inin-service training courses

According to the results of table 9, values of f-observed regarding educational needs, course contents, assessment methods, professors and teachers, and the increase in scientific and professional capabilities are significant at the level $\mathrm{P} \leq 0.05$; therefore, there is significant difference between ideas of respondents in different educational sections (primary, secondary, and high school). But, the value f-observed regarding educational environments and equipment and time of holding courses are not significant at the level $\mathrm{P} \leq 0.05$.

Table 10: comparing mean scores of respondents' ideas in terms of years of services regarding research variables in in-service training courses

\begin{tabular}{|c|c|c|c|c|c|c|c|c|c|c|c|c|}
\hline \multirow[b]{2}{*}{$\begin{array}{l}\text { Main research } \\
\text { questions }\end{array}$} & \multicolumn{2}{|c|}{$1-5$ years } & \multicolumn{2}{|c|}{ 6-10 years } & \multicolumn{2}{|c|}{$\begin{array}{l}11-15 \\
\text { years }\end{array}$} & \multicolumn{2}{|c|}{$16-20$ years } & \multicolumn{2}{|c|}{$\begin{array}{l}\text { Above } \quad 20 \\
\text { years }\end{array}$} & \multirow{2}{*}{$\begin{array}{l}\text { ANO } \\
\text { VA } \\
\\
\mathrm{f}\end{array}$} & \multirow{2}{*}{$\begin{array}{l}\text { Sig. } \\
\\
\\
\mathrm{P}\end{array}$} \\
\hline & $\begin{array}{l}\text { Me } \\
\text { an } \\
\text { sco } \\
\text { res } \\
\bar{x}\end{array}$ & SD & $\begin{array}{l}\text { Me } \\
\text { an } \\
\text { sco } \\
\text { res } \\
\bar{x}\end{array}$ & SD & $\begin{array}{l}\text { Me } \\
\text { an } \\
\text { sco } \\
\text { res } \\
\bar{x}\end{array}$ & SD & $\begin{array}{l}\text { Mea } \\
\text { n } \\
\text { scor } \\
\text { es } \\
\bar{x}\end{array}$ & SD & $\begin{array}{l}\text { Mea } \\
\text { n } \\
\text { scor } \\
\text { es } \\
\bar{x}\end{array}$ & SD & & \\
\hline $\begin{array}{l}\text { 1. Educational } \\
\text { needs of } \\
\text { in-service } \\
\text { training } \\
\text { courses }\end{array}$ & $\begin{array}{l}2.6 \\
5\end{array}$ & 0.8 & $\begin{array}{l}2.7 \\
1\end{array}$ & 0.85 & $\begin{array}{l}2.5 \\
8\end{array}$ & $\begin{array}{l}0.9 \\
5\end{array}$ & 2.36 & 0.89 & 2.6 & 0.9 & 0.871 & 0.482 \\
\hline $\begin{array}{l}\text { 2. Course } \\
\text { contents of } \\
\text { in-service } \\
\text { training } \\
\text { courses }\end{array}$ & $\begin{array}{l}3.3 \\
3\end{array}$ & 0.83 & $\begin{array}{l}3.0 \\
2\end{array}$ & 0.82 & $\begin{array}{l}3.1 \\
8\end{array}$ & $\begin{array}{l}0.9 \\
2\end{array}$ & 3.05 & 0.81 & 3.35 & 0.8 & 1.74 & 0.14 \\
\hline $\begin{array}{l}\text { 3. Assessment } \\
\text { methods of } \\
\text { in-service } \\
\text { training } \\
\text { courses }\end{array}$ & 3.1 & 0.55 & $\begin{array}{l}3.0 \\
9\end{array}$ & 0.7 & $\begin{array}{l}3.1 \\
9\end{array}$ & $\begin{array}{l}0.6 \\
5\end{array}$ & 3.12 & 0.54 & 3.21 & 0.65 & 0.371 & 0.829 \\
\hline $\begin{array}{l}\text { 4. Teachers } \\
\text { and }\end{array}$ & $\begin{array}{l}3.8 \\
4\end{array}$ & 0.67 & $\begin{array}{l}3.5 \\
8\end{array}$ & 0.7 & $\begin{array}{l}3.4 \\
4\end{array}$ & $\begin{array}{l}0.8 \\
8\end{array}$ & 3.63 & 0.68 & 3.59 & 0.64 & 1.406 & .232 \\
\hline
\end{tabular}




\section{Macrothink}

principals of in-service training courses

5. Educational environment $\mathrm{s} \quad$ and equipment of in-service training courses

6. Time of holding in-service training courses

7. Increase in scientific and professional 3.5 capabilities 5 inin-service training courses
0.77 2.8
6 
teachers' attitudes are the same. Professors and lecturers were evaluated as the highest rating levels and the increase in scientific and professional capabilities, course contents, assessment methods, time of holding courses, the environments and equipment, and finally educational needs were evaluated respectively as the lowest rates.

Comparing respondents' ideas based on demographic indicators (gender, years of service, educational sections, and status) indicated significant differences in several cases. The difference between male and female respondents' attitudes regarding research questions is only available regarding the degree of lecturers' and professors' skills used in in-service training courses and in other questions, there is no significant difference. In other words, female respondents evaluated professors' and lecturers' skills as higher than male students did. The difference between respondents' ideas in terms of educational sections considering the environments and equipment as well as the time of holding course had not significant difference. It means that individuals participating in educational courses whether from primary, secondary, or high schools had relatively same ideas about the environments and equipment as well as the time of holding course, but respondents' ideas in primary, secondary, and high schools regarding educational needs, course contents, assessment methods, processors and lecturers, and scientific and professional capabilities indicated significant differences.

In the way that primary school respondents evaluated need assessment of in-service courses as better than secondary and high school respondent did, it can be said that since most primary school principals and teachers have diploma and associate diploma, each kind of training can enhance their educational level; therefore this group evaluated educational needs as better than other respondents did.

Regarding course contents, primary school respondents evaluated these contents as more appropriate than high school ones did. In this regard, it can be said that since the scientific level of high school respondents is higher (BA/BSc and higher degrees) the content of courses at the same level with their academic level cannot satisfy them and they need course contents which give them more information.

Furthermore, primary school respondents evaluated assessment methods in in-service courses as more appropriate than other respondents did. In this regard, it can be said that secondary and high school respondents, regarding their own academic sections (higher than diploma) have been more familiar with correct assessment methods before in-service training course than primary school respondents and do not consider assessment merely at the end of courses with some multiple-option and descriptive tests; therefore, it seems that secondary and high school respondents have negative evaluations towards assessment methods in in-service courses because in most of these courses, assessment is not been conducted scientifically.

Regarding the fact that there is significant differences between primary school and high school respondents regarding the degree of professors' and lecturers' skills in in-service training courses, it can be said that since most professors and lecturers used in these courses were from Educational Organization not from universities, i.e. individuals with similar educational levels with high school individuals participating in courses, and the only 
privilege of these professors to respondents was their years of services and experiences; therefore, primary school respondents evaluated them as better than high school respondents did.

In addition, there is significantdifferences between primary and high school respondents' ideas regarding the increase in scientific and professional capabilities. It means that primary school respondents evaluated their own increase in scientific and professional capabilities higher than high school respondent did their own. In this regard, it can be said that since primary school respondents have evaluated need assessment of course, course contents, assessment methods, and lectures and professors as more appropriate, in general, their attitudes towards the increase in scientific and professional capabilities are positive.

There is a significant difference between respondents' ideas in terms of years of service regarding research questions. In other words, respondents with 16-20 years of service or more than 20 years evaluated need assessment of courses, course contents, assessment methods, professors and lecturers, environments and equipment, time of holding courses, and the increase in scientific and professional capabilities as better and more appropriate than respondents with less years of service did.

In this regard, it can be said that individuals with many years of service view in-service courses only as course for achieving higher rates from which they can use in their retirement and use their advantages. It may be due to this reason that this group, regarding their many years of service and due to the fact that they have had expressed these comments as frequently as possible and they have received less results, they have more tendency to answer the questions at moderate levels and this reason can distinct them from other groups (with less than 16 years of service).

\section{References}

Azar, R. (2005). Analysis of the quality of principals' in-service training courses and providing proper training patterns. MA thesis, University of Tehran.

Alexander, G.E. 2006. IGE as a Focus for Reorganizing persevere and in-service. Teacher Education in ohio. Journal of teacher Education, 27(3). P.P. 244-249.

Brimm, J.L. and Tollett, D.J. 1984. How Do Teachers feel about in-Service Educational leadership research Supplement. P.P. 521-525.

Batistoni, J.L, 2001. Factors promoting and constraining in-service Education. Journal of Teacher Education, 29(3). P.P. 31-33.

Bunker, R.M. (1987). Beyond in-service: Towards staff renewal. Journal of teacher education, 28, 2, 31-34.

Edelfelt, R.A. 1984. In-service Education of Teachers: Priority for the next decade. The Journal of teacher education, 25(3).P.P. 250-252. 


\section{Macrothink}

International Journal of Human Resource Studies

ISSN 2162-3058 2016, Vol. 6, No. 1

Fathi, A. and Ejargah, K. (2007). An introduction to the planning of staff in-service training courses. Tehran: SaramadKavosh.

Flatter, C.H. and Koopman. E.J. 1986. An in-service Self Study program: The forgotten key to Educational success. Journal of teacher education, 27(2).P.P. 116-119.

Ghanbari, K. (2003). The impact of management training on the performance of elementary school principals from teachers' views. Unpublished MA thesis, Teacher Training University of Tehran.

Ghoshouni, A. (2005). Evaluation of the new system of high quality in-service training from viewpoints of participants. Master's thesis, University of Tehran.

Information and Statistics Department of Education Isfahan Province (2010).

Izadi, R. (2002). The efficiency and effectiveness of in-service training of primary school teachers with associate diploma. Master's thesis of Educational Planning,Mazandaran University.

Kazemi, H. (1991). Bases of research in the behavioral sciences. Tehran: Paik Farahang Publication.

Javadian, Gh. (2005). Investigate the factors affecting the degree of students in technical schools in Tehran from short in-service training courses form teachers and students' attitudes. Unpublished master's thesis, Islamic Azad University, Tehran.

Mir Kamali, M. (1998). In-service training, the most fundamental factor of organizational renovation. Journal of Management Education, pp.5-10, the fifth vol.

Saco, J.M. and Cook, J.M. 1986. Learning Hierarchies Improve teacher's Attitude toward Accountability. Journal of teacher Education, 27(2). P.P. 113-115.

TighsazZadeh, M. (2002). Evaluation of management in-service training of the staff and its role in human, technical, problem-solving, and decision-making areas. Unpublished master's thesis, University of Tehran.

William, K.J. 1989. Creating a context for Curriculum Deliberation by Teachers. Dissertation Abstracts International, 53.

Winterton, W. 1987. Let's get serious about in-service. Journal of teacher Education, 28(2). P.P. 35-37.

ZarrinGohar, H. (1987). The effectiveness of in-service training on the staff efficiency in Tehran Education Department. Master's thesis, University of Tehran. 